한국사회체육학회지, 제52호. pp. 119 134

Journal of Sport and Leisure Studies

2013. Vol. 52. pp. 119 134

\title{
A Development of Motivation Scale of Sport Website Users: A Perspective of Motivation Factors on Attitude and Behavioral Intention
}

Lee, Soon-Hwan (Indiana University Purdue University Indianapolis) $\cdot$ Choi, Wan-Yong (Indiana University at Bloomington) · *Shin, Hong-Bum (Keimyung University) · Choi, Hyong-Jun (Dankook University)

\section{INTRODUCTION}

Since the advent of the Internet from the late 1980s, utilization of internet has become a dominant social and technical tool with informational and interactive communication capabilities in our society. The internet, especially, as an interactive communication method has become an important part of the younger generation's life for the last decade (Gemmill \& Peterson, 2006; Subrahmanyam \& Greenfield, 2008; Subrahmanyam, Reich, Waechter, \& Espinoza, 2008). According to the Pew Research Center (2009), approximately 79\% of American adults used the Internet in 2009. Another recent report from the Internet World Stats (2011) reported more than 2 billion people worldwide used the Internet in 2011. People use the Internet for numerous reasons, such as communication, interaction, information, entertainment, and escapism (December, 1996; Eighmey \& McCord, 1998; Koraonkar \& Wolin, 1999).

Main motives of using the Internet are to seek certain information and for social interaction. Seeking social interaction through the Internet is to use experience for social connection and interaction. Social interaction and information seeking as instrumental uses are generally linked to watching specific program types including news and sports (Cooper \& Tang, 2009).

Of the numerous benefits of using the Internet, many people go online for the purpose of accessing sportrelated information. Madden (2003) reported about 44\% of Internet users have used the Internet to look for sport related information. Sports web sites, such as ESPN Sportszone, Yahoo! sports, ESPN Cricinfo, NBA. com, NFL.com, Fox Sports, Live Score, SI.com, FIFA, and WWE, which are the top 10 most popular sport websites, frequently draw heavy Internet traffic (Stoldt, Ditmore, \& Pedersen, 2011; Top Site Blog, 2011).

*shinhb@kmu.ac.kr 
A volume of previous studies have examined several areas of sport websites, such as contents of sport website (Duncan \& Campbell, 1999; Smith, Pent, \& Pitts, 1999), sport website user rates or website user demographic information (Brown, 2003; Duncan \& Campbell, 1999), and traditional marketing mix content information (Brown, 2003; Filo \& Funk, 2005) due to the strong influence and importance of Internet usage among sport fans. However, as Beech, Chadwick, and Tapp (2000) stated, these previous studies have provided limited information regarding only users' demographics and tracking users' movement rather than exploring motives of using the Internet and gratifications of the experience.

While the Internet and its user motivations have been the subjects of a number of mass media paradigms with application of the uses and gratifications ( $U \& G$ ) theory, it is necessary and important to adapt the U\&G theory for the greater understanding of sport website users' motivations. Thus, the current study employs the U\&G theory to develop a motivation scale of sport website users and consider how the motivation factors influence the formation of attitude towards using the sport websites. U\&G theory is a psychosocial approach to understanding what and how people use media to fulfill their specific gratifications (Rubin, 1993). With a key element of research question that attempted to understand why Internet users visit certain websites, U\&G theory has been adopted by many mass communication and media studies to examine antecedents, motives, and outcome of communication within interpersonal and mediated contexts (Newhagen \& Rubin \& Bantz, 1987).

\section{Motivational Use of Sport Websites}

Sport websites have become a very important communication medium for sport organizations and sport related commerce, who develop the contents of websites to deliver a variety of information and to communicate with the target consumers. Therefore, understanding sport website users' motives is a vital issue because it provides insights to develop effective promotional or marketing strategies.

While many research regarding sport websites have focused on methods for generating revenue through sport websites, the level of intention to purchase products through sport websites, and establishing customer loyalty (Brown, 2003; Caskey \& Delpy, 1999; Pope, Brown, \& Forrest, 1999), there has been a dearth of research that developed and proposed a formal scale of motivation for sport website users. According to a few studies that explored sport websites, several motives of sport website users are identified. Hur, Ko, and Valacich (2007) used structural equation modeling to explore the online consumption behavior of sport. They provided five factors of motivation in online sport consumption (e.g., convenience, information, diversion, socialization, and economic) and four factors of concerning online sport consumption (e.g., security and privacy, delivery, product quality, and customer service). 


\section{Motives of Uses and Gratifications of the Internet}

Motives are psychological dispositions that influence people's behaviors to meet a need or want (Papacharissi \& Rubin, 2000). While motives are commonly used as the key components to examine people's activity and perception of using media in mass communication studies, many sport management research adapted the motives for understanding sport consumer behavior.

U\& $G$ theory delineates motivational experience through media uses and need gratifications (Kang, Lee, \& Lee, 2010). Numerous mass media studies employed U\&G theory to find various motivational impacts into different communication media mediums, such as newspapers, TV, radio, and the Internet (Blumler, 1979; Lin, 1999; Papacharissi \& Rubin, 2000). U\&G theory also was applied to explain not only the uses of communication, but also their sociological and psychological origins (Blumler, 1985). Additionally, U\&G theory is widely used to explain psychological processes such as how and why people select and use media and engage its media-use behavior for gratification (Rubin, 1994; Severin \& Tankard, 1997; Swanson, 1987). The main objective of U\&G theory is to explain people's psychological needs for media usage, and people's engagement into certain media use behaviors for gratification that satisfy the people's needs and wants (Rubin, 1994; Ko, Cho, \& Roberts, 2005).

Despite ever-increasing popularity of sport websites, there has been a scarcity of research in development of motivation scale for sport website users. With the aforementioned emphasis on the Internet users' perspective, applying U\&G theory is appropriate to the study of developing a motivation scale of sport website users. In order to develop a motivation scale of sport website users, the items of the scale were adopted and modified from the previous instruments (Ahn, 2010; Ko, Cho, \& Roberts, 2005; Papacharissi \& Rubin, 2000).

By applying the $U \& G$ theory perspective through the review of literatures, five key motives for visiting sport related websites were identified and termed: entertainment, interactivity, information, convenience, and economic. Entertainment motivation can be described as the extent to which the Internet provides a fun, exciting, relaxation, and enjoyable factor (Eighmey \& McCord, 1998; Luo, 2002). Across different sport fan motivation and Internet user motivation studies, entertainment is a common factor to consume sport and website, respectively (Chen \& Wells, 1999; Farquhar \& Meeds, 2007; Funk, Mahony, \& Ridinger, 2002; Funk, Ridinger, \& Moorman, 2003; Ko, Cho, \& Roberts, 2005; Luo, 2002; Wann, 1995). Interactivity is a unique marketing tool compared to other media such as TV, radio, and print media (Brown, 2003). It can be described as the extent to which users can share personal opinions and experiences as the various forms of social interaction. For instance, the websites with interactivity functions to communicate with users are considered to be more popular websites than the websites without any interactivity contents (Ghose \& Wenyu, 1998; O’Keefe, O'Connor, \& Kung, 1998). In the same manner, customized interactive functions provide more suitable information based on the consumers' needs that increase the level of positive perception and attitude toward the website consumers (Hwang \& McMillan, 2002; Liu, 2003; Raney, 2006). Information can be defined as the extent to which 
websites provide useful and knowledgeable information (Chen \& Wells, 1999). Internet users can easily gather useful information about their favorite sport such as game score, player information, ticket availability and price, and game schedule. Convenience can be described as the extent to which the Internet provides an ease of using its functions. For example, people easily use the Internet for various purposes such as emailing, e-commerce activity, and searching for necessary information. The economic factor can be described as the extent to which sport website users are able to obtain economic gains while accessing a sport website (Ahn, 2010). For instance, people can sell or buy sport related products or do any kind of gambling activity in appropriate sport websites. Whereas the economic factor has been widely studied and is considered an important factor in mass media research (Korgaonkar \& Wolin, 1999; Rodgers \& Sheldon, 2002), sport management studies have lightly discussed and applied this factor (economic factor) in the sport consumer behavior dimensions.

\section{Attitudinal and Behavioral Intention of Using Sport Websites}

While many mass media literatures show attitude as an important correlated medium to predict the types and patterns of media use (Garramone, Harris, \& Anderson, 1986; Papacharissi \& Rubin, 2000; Perse, Burton, Kovner, Lears, \& Sen, 1992; Rubin, 1983), sport management literatures apply the concept of attitude for marketing or sponsorship perspective. As such, research suggests that exposure to the Internet can enhance attitude toward visiting and/or using sport related websites. That is, the more the people are exposed to the Internet, the more the people are likely to build an attitude toward visiting and/or using sport related websites.

Attitude is an essential concept in explaining human behavior. Attitude is defined as the degree to which an individual has a predisposition or appraisal of a class of behavior (Ajzen, 1991; Fishbein \& Ajzen, 1975; Triandis, 1971). Attitude toward behavior refers to the degree to which one has a favorable or unfavorable appraisal of the action. Thus, the attitude theory suggests that the more favorable attitude people have towards a given object, the more likely that people are to use that object (Ajzen \& Fishbein, 1980; Karjaluoto, Mattila, \& Pento, 2002). As suggested by Ajzen and Fishbein (1980), the overall attitude towards an object is expected to be related to behavior towards the object. A number of previous social psychology studies have indicated that attitude has both affective and cognitive components (Cialdini, Petty, \& Cacioppo, 1981; Crites, Fabrigar, \& Petty, 1994; Fabrigar \& Petty, 1999; Millar \& Tesser, 1986; Ostrom, 1969; \& Petty, 1997). Attitude that has affective and cognitive components influences individuals' behavioral intention. Hence, the theoretical literatures of attitude, the current study, implied different factors of motivations impact on attitude (affective and cognitive) and behavior intention toward using the sport websites. Individual's attitude toward performing the behavior is a function of the perceived consequences of carrying out a specific action and the individual evaluation of these consequences (Valois, Desharnais, \& Godin, 1988). Thus, an individual's intention to behavior is the level of an individual's planned-willingness and efforts to try the behavior (Ajzen, 1991). Additionally, since 
the current study is to explore the intentions of using sport websites, the condition of actual usage of sport websites is also important. Some related studies found that behavioral intention might influence usage of the object (Bagozzi, Davis, \& Warshaw, 1992; Curran, Meuter, \& Surprenant, 2003; Jackson, Chow, \& Leitch, 2007; Sheeran, 2002; Szajna, 1996).

The research questions guiding the current study are as follows and the overall conceptual framework is displayed in $<$ Figure $1>$.

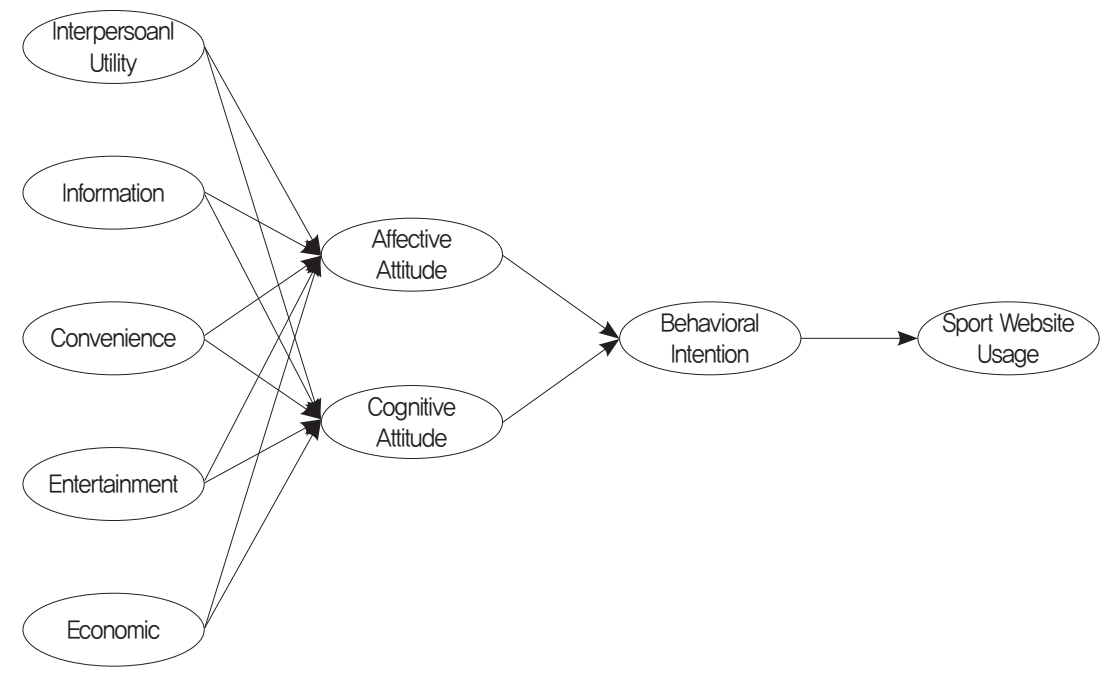

Figure 1. Conceptual Framework

\section{Research Questions}

The current study seeks to develop a motivation scale of sport website users and consider the impact of different factors of motivations on attitude (affective and cognitive) and behavior intention toward using the sport websites. A series of research questions were developed and posed:

\section{Research Questions:}

RQ1: Which motivation factor is considered as the most important for sport website users?

RQ2: What are the significant difference of demographic characteristics and distributions of sport website users?

RQ3: Based on dimensions of gratifications, are there any clear motivational categories for sport website users? 


\section{II . METHOD}

\section{Instrumentation}

The data collection method of this study was a self-administered paper survey comprised of 35 separate items and included a series of questions relating to the following areas: 1) demographic information (10 items), 2) five motivation information (i.e., interpersonal utility, information, convenience, entertainment, economic; 19 items), and 3) attitude information (affective and cognitive attitudes; 6 items). In order to develop a motivation scale of sport website users, the items of scale were modified and developed from the previous instruments (Ahn, 2010; Ko, Cho, \& Roberts, 2005; Papacharissi \& Rubin, 2000). The survey was developed with a 7-point Likert scale from "strongly disagree" (1 on the scale) to "strongly agree" (7 on the scale). Each of the items followed the same pattern. $<$ Table $1>$ shows the specific sources of each measure.

Table 1. Generated Five Motivation and Attitudes Instrument Dimensions and Items

\begin{tabular}{cl}
\hline Dimension & \multicolumn{1}{c}{ Item } \\
\hline Interpersonal Utility & "Ivisit and use the sport websites: \\
\hline to participate in discussion topics \\
because I enjoy answering questions in the discussion \\
to give my input
\end{tabular}

\section{Pilot Test}

To determine the reliability of the proposed factors, a pilot study was conducted. The sample was consisted of faculty and undergraduate students from a large Midwestern university $(n=85)$ in the U.S. The content valid- 
ity of the questionnaires was verified using a panel of experts. Five panel members were asked to review each of the questionnaires carefully to determine whether the individual items adequately represented the domains of the constructs. All of the experts agreed that the original questionnaires adopted and modified by the researchers were acceptable for use in data collection. Each proposed factor and corresponding list of items were examined for reliability independently of the other factors and their corresponding items. Cronbach's Alpha was calculated for each factor and the factor loadings for each item were also determined. The reliability scores (Cronbach's Alpha) for the seven proposed factors were stable (Entertainment $=.861$, Interactivity $=.858$, Information $=.813$, Convenience $=.787$, Economic $=.765$, Cognitive $=.753$, Affective $=.750$ ). Another important consideration when examining a model is discriminant validity. Factors should correlate with each other but not so strongly that they represent the same construct (i.e., <.90, Tabachnick \& Fidell 2001). It was assumed to this point that these factors are all related to each other as representative of a single higher motivation to use sport websites.

\section{Sample Data Collection}

The primary data were obtained using a convenience sampling method in the spring semester of 2012 (February 28 - March 29). Paper questionnaires were distributed and collected from the students ages 18 or over at a large Midwestern university in the U.S. A total of 505 responses (70.1\%) were garnered for main analysis.

The sample of respondents was consisted of 266 males (52.7\%) and 239 female (47.3\%). More than 99.6\%

Table 2. Descriptive Statistics Analysis of Sample Size

\begin{tabular}{|c|c|}
\hline Respondents' characteristics & $\mathrm{N}=505$ \\
\hline \multicolumn{2}{|l|}{ Gender } \\
\hline Male & $266(52.7 \%)$ \\
\hline Female & $239(47.3 \%)$ \\
\hline \multicolumn{2}{|l|}{ Grade } \\
\hline Freshmen & $140(27.7 \%)$ \\
\hline Sophomore & $113(22.4 \%)$ \\
\hline Junior & $132(26.1 \%)$ \\
\hline Senior & $118(23.4 \%)$ \\
\hline Graduate & $2(0.4 \%)$ \\
\hline \multicolumn{2}{|l|}{ Ethnicity } \\
\hline African American & $65(12.9 \%)$ \\
\hline Asian/Pacific Islander & $12(2.4 \%)$ \\
\hline Caucasian & $391(77.4 \%)$ \\
\hline Hispanic & $19(3.8 \%)$ \\
\hline Native American & $3(0.6 \%)$ \\
\hline Other & $15(3.0 \%)$ \\
\hline
\end{tabular}


of the respondents were freshmen, sophomore, junior, or senior students. For the status of ethnicity, the majority of survey respondents were Caucasian $(n=391,77.4 \%)$, followed by African American $(n=65,12.9 \%)$, Hispanic $(n=19,3.8 \%)$, Asian $(n=12,2.4 \%)$, Native American $(n=3,0.6 \%)$, and other $(n=15,3.0 \%)$. Specific descriptive statistics are provided in $<$ Table $2>$.

\section{Data Analysis}

Descriptive statistical analysis was employed to analyze the demographic information of sport website users. t-test and one-way ANOVA were also utilized to compare gender difference for using pattern of sport website. Further, the reliability (Cronbach's alpha) of each subscale was measured with SPSS 18.0, when the coefficients value is greater than .70, it is considered as an acceptable level to get adequate internal consistency (Nunnally \& Bernstein, 1994). In addition, based on the correlation result, the validity of each construct was determined. To get an acceptable level of validity, the correlation value should not greater than .90 (Tabachnick \& Fidell, 2001).

A confirmatory factor analysis (CFA) was employed to assess the consistency between the hypothesized structure and the structure found in the data. This analysis was conducted using the procedures outlined in Byrne (2006) and Hatcher (1994). The $\chi^{2}$ and df, the comparative fit index (CFI), the root-mean-square error of approximation (RMSEA) and standard root-mean-squared residual (SRMR) were used to assess the overall model fit.

A structural equation modeling was used to develop the motivation scale of sport website users and consider how different factors of motivations impact on attitude (affective and cognitive) and behavior intention toward using the sport websites.

\section{RESULTS}

\section{Descriptive Results}

In regarding of using internet hours, $7.9 \%$ of respondents using internet less than 1 hour per day, 50.7\% answered 1-3 hours, 32.3\% responded 4-6 hours, 6.5\% have used 7-9 hours per day. Also, regarding experience to visit sport website, $78.6 \%$ of respondents had experience to visit various sport website. Specifically, among 266 male respondents, 243(91.4\%) of sample had an experience to visit sport website, and among 239 female respondents, 154(64.6\%) of respondents had an experience.

When it comes to using sport website hours, t-test result indicated that there was a significant difference between male and female but there was no meaningful difference for using internet using hours. Also, one- 
way ANOVA results revealed that there was no statistically significant difference for internet using hours among several of income levels.

\section{Measurement Model}

$<$ Table $3>$ indicates correlations, means, and standard deviations of the measures. Also, Confirmatory factor analysis for the proposed measurement model of five motivation factors (i.e., interpersonal utility, information, convenience, entertainment, economic) and attitudes (affective attitude and cognitive attitude) satisfied the model fit. Chi-square value $\left(\chi^{2}=518.006, \mathrm{df}=188, \mathrm{p}<.001 ; \mathrm{CFI}=.979\right.$; SRMR $\left.=.021 ; \mathrm{RMSEA}=.059\right)$ measurement model fit the data. $<$ Table $4>$ shows factor loadings, reliability coefficients, and AVE values. All factor loading values were positive and significant at $\mathrm{p}<.05$ level, ranging from .836 to 967 . All reliability coefficients were higher than .70, ranged from .941 to .971 and AVE values were acceptable level (Hair et al., 2005).

Table 3. Descriptive Statistics and Correlations among Variables

\begin{tabular}{cccccccc}
\hline Variable & 1 & 2 & 3 & 4 & 5 & 6 & 7 \\
\hline 1. Interpersonal & 1 & & & & & & \\
2. Information & $.398^{* *}$ & 1 & & & & & \\
3. Convenience & $.525^{* *}$ & $.838^{* *}$ & 1 & & & & \\
4. Entertainment & $.480^{* *}$ & $.791^{* *}$ & $.771^{* *}$ & 1 & & & \\
5. Economic & $.518^{* *}$ & $.469^{* *}$ & $.549^{* *}$ & $.510^{* *}$ & 1 & & \\
6. Affective & $.557^{* *}$ & $.627^{* *}$ & $.638^{* *}$ & $.751^{* *}$ & $.595^{* *}$ & 1 & $.853^{* *}$ \\
7. Cognitive & $.517^{* *}$ & $.726^{* *}$ & $.696^{* *}$ & $.788^{* *}$ & $.573^{* *}$ & 1 \\
\hline M & 2.62 & 4.84 & 4.39 & 4.60 & 3.12 & 3.64 & 4.02 \\
SD & 1.53 & 1.74 & 1.51 & 1.90 & 1.69 & 1.90 & 1.90 \\
\hline
\end{tabular}

\section{Structural Model}

The proposed model was specified by structural relationship among interpersonal utility, information, convenience, entertainment, economic, affective attitude, and cognitive attitude satisfied model fit [Chi-square value $\left.\left(\chi^{2}=557.661, \mathrm{df}=228, \mathrm{p}<.001 ; \mathrm{CFI}=.979 ; \mathrm{SRMR}=.023 ; \mathrm{RMSEA}=.054\right)\right] .<$ Figure $2>$ indicates parameter estimates for the structural model. Interpersonal utility, entertainment, and economic motivation factors positively and significantly influence both affective and cognitive attitudes, respectively. Information motivation factors positively and significantly influence only on cognitive attitude. On the other hand, convenience motivation factors negatively and non-significantly influence both attitude factors. Further, both affective attitude and cognitive attitude showed non-significant impact on inter using. However, internet using factor positively and significantly impacts on sport website using. 
Table 4. Summary results for confirmatory factor analysis

\begin{tabular}{|c|c|c|c|}
\hline Factors and items & Factor loading & $\alpha$ & AVE \\
\hline \multicolumn{4}{|l|}{ "I visit and use the sport websites: } \\
\hline Interpersonal Utility & & .951 & .684 \\
\hline to participate in discussion topics & .921 & & \\
\hline because I enjoy answering questions in the discussion & .958 & & \\
\hline to give my input & .913 & & \\
\hline Information & & .941 & .938 \\
\hline to get information for free & .836 & & \\
\hline to learn about unknown things & .860 & & \\
\hline because information obtained from the sport website is helpful & .949 & & \\
\hline because information obtained from the sport website is useful & 939 & & \\
\hline Convenience & & .955 & 677 \\
\hline because it provides information very quickly & .930 & & \\
\hline because I can obtain information without any delay & .939 & & \\
\hline because I can get instantaneous information when desired & .942 & & \\
\hline Entertainment & & .971 & .729 \\
\hline because I just like to use & .944 & & \\
\hline because it is enjoyable to me & .974 & & \\
\hline because it is fun to use & .959 & & \\
\hline Economic & & .955 & .587 \\
\hline because I can purchase sports products through the sport website & .926 & & \\
\hline because it provides access to convenient shopping & .958 & & \\
\hline because I can find good deals on sports products & .927 & & \\
\hline Affective Attitude & & .966 & .719 \\
\hline Using the sport website makes me pleasant & .942 & & \\
\hline Using the sport website makes me enjoyable & .967 & & \\
\hline Using the sport website makes me feel good & .948 & & \\
\hline Cognitive Attitude & & .959 & 670 \\
\hline Using the sport website is beneficial to me & .923 & & \\
\hline Using the sport website is a wise choice to me & .960 & & \\
\hline Using the sport website is valuable to me & .944 & & \\
\hline
\end{tabular}

\section{DISCUSSION AND CONCLUSION}

The results was discussed in the current study was on the line with previous literatures which addressed the relationship among Internet use motivation, attitude, behavioral intention, and usage (Bagozzi, Davis, \& Warshaw, 1992; Curran, Meuter, \& Surprenant, 2003; Jackson, Chow, \& Leitch, 2007; Kang, Lee, \& Lee, 2010; Papacharissi \& Rubin, 2000; Sheeran, 2002; Szajna, 1996). The current study could explore the motivations of sport website users' experience of using internet. Interpersonal utility, information, entertainment, and economic motivation factors influence the attitudes, but convenience motivation factors were not significant related to attitudes. Especially, entertainment motivation factors dominantly influence on attitude which was 


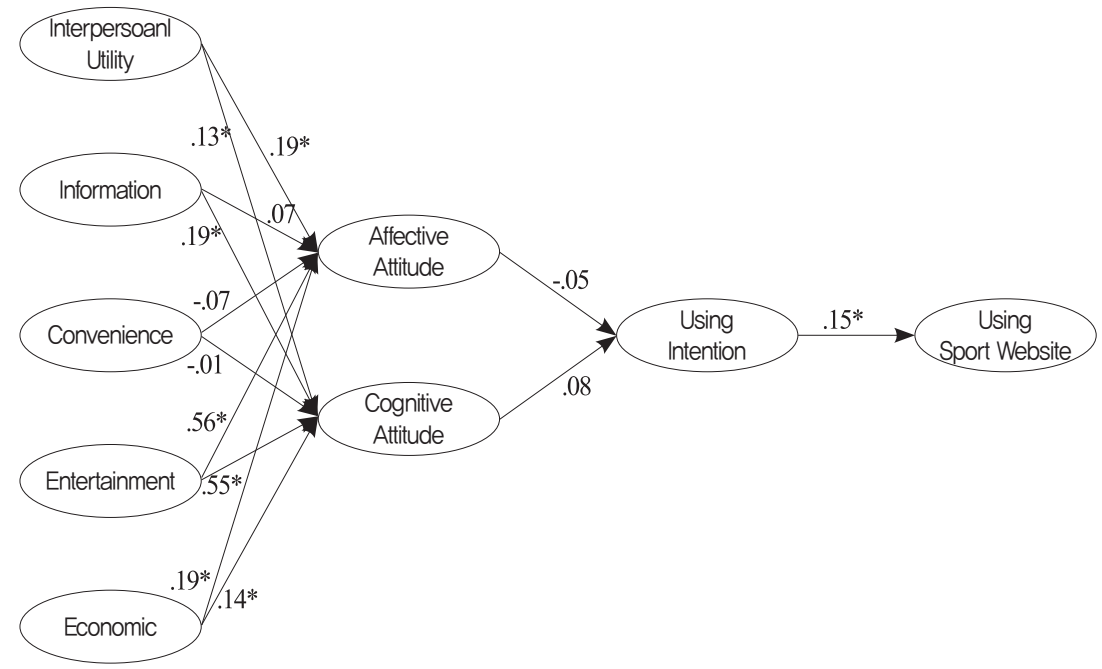

Figure 2. Structural Model for Interpersonal Utility, Information, Convenience, Entertainment, Economic, Affective Attitude and Cognitive Attitude

consistent with the fact, based on the sport fan motivation and internet user motivation literatures, entertainment was a common factor to use sport and website, respectively (Chen \& Wells, 1999; Farquhar \& Meeds, 2007; Funk, Mahony, \& Ridinger, 2002; Funk, Ridinger, \& Moorman, 2003; Ko, Cho, \& Roberts, 2005; Luo, 2002; Wann, 1995). This is very meaningful for sport related website practitioners and this information can be applied to sport marketing websites as a primary goal for website users who seek a type of fun and enjoyment as for their leisure activity. In addition, it is in the line with the one of the functions of sport-program-viewing motives which was argued by Birrell and Loy (1979) and Wann's (1995) motivational factors of sports fan: escape, aesthetics, entertainment, group affiliation, and family needs. It implied a main goal of sport website users was looking for a sort of enjoyment in their ordinary routines.

The results of the current study also revealed interesting fact that convenience motivation was not an important factor for attitude for using sports website. It indicated that development of technology devices provide that people access internet easier and get information faster. Technology devices, such as smartphone, tablet PC, and birth of social network services (i.e., Twitter, Facebook, and LinkedIn) accelerate this trend and change to make people easily access information they need. In other words, people are not in need of accessing sport related website in order to get information because other convenient and handy technology devices provide a variety of sports related information.

Useful and practical implications for sport website practitioners could be provided as follows based on the results of the current study. First, when sport organizations or commerce construct sports website, it is suggested to be aware that the purposes and features of website operation. It implied that sport website practitioners should consider the factors of interaction, information, entertainment, and economic which are related to affective and cognitive attitude factors for website users. Second, regarding interaction and information 
factors, sport website practitioners should consider keeping interaction with their website users in order to present a variety and enough volume of information. It is very important to provide information that website users like to acquire. In specific, sport website practitioners should identify what kinds of information (i.e., player profiles, specified data analysis, player life story, and team pictures) website users want to know or get through their website, continuously. In addition, sport website practitioners should provide a website space which the users are able to discuss and exchange their opinions for certain issues. Reflecting the interaction might make sport website to be an efficient space for both interaction and information factors. Third, sport website practitioners should need to consider unique factors of the website that make website users to be enjoyable. Uniqueness is one of the very effective tools to make enjoyable website in the competitive situation among other sport related websites. For instance, sport website practitioners should try to provide websites users for various enjoyments (i.e., exclusive column from eminent journalist or analysis, established retired player, and event of score or result prediction) in which cannot be experienced at other sports websites. Therefore, sport website practitioners should make a constant effort for enjoyable website because enjoyment and knowledge of attitude factors might be one of important marketing ways to increase the rate of website usage as a practical marketing strategy. Fourth, as telecommunications technologies develop, people purchase a variety of sports related products through sports related website. Thus, sport website practitioners should develop a type of special priced-oriented promotion or exclusive membership for website users who buy sports related products through their websites. Accessing to convenient shopping with affordable prices is one of the main reasons people use sport websites and those examples are much related with economic motivation factor.

\section{V . LIMITATIONS AND DIRECTIONS FOR FUTURE RESEARCH}

As with any research endeavor, the current study was not an exception as it had several limitations and directions for future research. The current study was employed limited motivation factors and attitudes which were focused on only sport website users. Thus, future study should aim to find additional motivation factors which might influence attitude and behavioral intention (i.e. including technology device users' motivation factors). The date for the current study was collected only at a Midwestern university in the U.S with the convenient sampling method. Thus, future study should explore to measure the relationship among various motivation factors and attitude and usage of sport websites with larger sample to generalize the result of the study. Furthermore, trend of accessing internet and social network service (SNS) factors using telecommunication devices also should be considered in the future research because introduction and development of new technological devices such as smartphone and tablet PC make people can access internet without any other restriction of time and place. 


\section{- References}

Ahn, T. (2010). The effect of user motives and interactivity on attitude toward a sport website. Unpublished doctoral dissertation, Florida State University, Tallahassee.

Ajzen, I. (1991). The theory of planned behavior. Organizational Behavior and Human Decision Processes, 50(2), 179-211.

Ajzen, I., \& Fishbein, M. (1980). Understanding attitudes and predicting social behavior. New York, NY: Prentice-Hall.

Bagozzi, R. P., Davis, F. D., \& Warshaw, P. R. (1992). Development and test of a theory of technological learning and usage. Human Relations, 45(7), 659-686.

Beech, J., Chadwick, S., \& Tapp, A. (2000). Surfing in the premier league: Key issues for football club marketers using the Internet. Managing Leisure, 5(2), 51-64

Bentler, P. M. (2005). EQS program manual. Encino, CA: Multivariate Software, Inc.

Birrell, S., \& Loy, J. (1979). Media sports: Hot and cool. International Review of Sport Sociology, 14(1), 5-19.

Blumler, J.G. (1985). The social character of media gratifications. In K.E. Rosengren, L.A. Wenner, \& P. Palmgreen (Eds.), Media gratifications research (pp. 41-59). Beverly Hills, CA: Sage.

Brown, M. T. (2003). An analysis of online marketing in the sport industry: User activity, communication objectives, and perceived benefits. Sport Marketing Quarterly, 12(1), 48-55.

Browne, M.W., \& Cudeck, R. (1992). Alternative ways of assessing model fit. Sociological Methods \& Research, 21, 230-258.

Byrne, B. M. (2006). Structural Equation Modeling with EQS (2nd ed.). Manwah, NJ: Lawrence Earlbaum.

Caskey, R. J., \& Delpy, L. A. (1999). An examination of sport web sites and the opinion of web employees toward the use and viability of the World Wide Web as a profitable sports marketing too. Sport Marketing Quarterly, 8(2), 13-34.

Chang, W., \& Lee, S. (2001). An investigation of college students' sport program viewership. Journal of Sport Views and Issues, 2(2). Retrieved November 18, 2011, from http://sptmgt.tamu.edu/VOLUME3LEE.htm

Chen, Q., \& Wells, W. D. (1999). Attitude toward the site. Journal of Advertising Research, 39(5), $27-38$.

Cialdini, R. B., Petty, R. E., \& Cacioppo, J. T. (1981). Attitude and attitude change. Annual Review of Psychology, 32, 357-404.

Cooper, R., \& Tang, T. (2009). Predicting audience exposure to television in today's media environment: An empirical integration of active-audience and structural theories. Journal of Broadcasting and Electronic Media, 53(3), 400-418.

Crites, S. L. Jr., Fabrigar, L. R., \& Pettry, R. E. (1994). Measuring the affective and cognitive properties of attitudes: Conceptual and methodological issues. Personality and Social Psychology Bulletin, 20(6), 619-634.

Curran, J. M., Meuter, M. L., \& Seprenant, C. F. (2003). Intentions to use self-service technologies: A confluence of multiple attitudes. Journal of Service Research, 5(3), 209-224.

December, J. (1996). Units of analysis for Internet communication. Journal of Communication, 46(1), 14-38.

Duncan, M., \& Campbell, R. M. (1999). Internet users: How to reach them and how to integrate the Internet into the marketing strategy of sport business. Sport Marketing Quarterly. 8(2), 35-41.

Eighmey, J. \& McCord, L. (1998). Adding value in the information age: Uses and gratifications of sites on the World Wide Web. Journal of Business Research, 41(3), 187-194.

Fabrigar, L. R., \& Petty, R. E. (1999). The role of the affective and cognitive bases of attitudes in susceptibility to affectively and cognitively based persuasion. Personality and Social Psychology Bulletin, 25(3), 363-381.

Farquahar, L. K., \& Meeds, R. (2007). Types of fantasy sports users and their motivations. Journal of Computer-Mediated Communication, 12(4), 1208-1228.

Filo, K., \& Funk, D. C. (2005). Congruence between attractive product features and virtual content delivery for Internet marketing communication. Sport Marketing Quarterly, 14(2), 112-122.

Fishbein, M., \& Ajzen, I. (1975). Belief, attitude, intention and behavior: An introduction to theory and research. Reading, MA: AddisonWesley. 
Funk, D. C., Mahony, D. F., \& Ridinger, L. L. (2002). Characterizing consumer motivation as individual difference factors: Augmenting the sport interest inventory (SII) to explain level of spectator support. Sport Marketing Quarterly, 11(1), 33-43.

Funk, D. C., Ridinger, L. L., \& Moorman, A. M. (2003). Understanding consumer support: Extending the sport interest inventory (SII) to examine individual differences among women's professional sport consumers. Sport Management Review, 6(1), 1-31.

Garramone, G. M., Harris, A. C., \& Anderson, R. (1986). Uses of political computer bulletin boards. Journal of Broadcasting \& Electronic, 30(3), 325-339.

Gemmill, E., \& Peterson, M. (2006). Technology use among college students: Implications for student affairs professionals. NASPA Journal, 43(2), 280-300.

Ghose, S., \& Wenyu, D. (1998). Interactivity functions and their impacts on the appeal of Internet presence sites. Journal of Advertising Research, 38(2), 29-44.

Hatcher, L. (1994). A step by step approach to using SAS for factor analysis and structural equation modeling. Cary, NC: SAS Publishing.

Hu, L.T., \& Bentler, P.M. (1995). Evaluating model fit. In Structural equation modeling: concepts issues and applications, ed. R. H. Hoyle 76-99. Thousand Oaks, CA: Sage.

Hu, L. T., \& Bentler, P. M. (1999). Cutoff criteria for fit indexes in covariance structure analysis: Conventional criteria versus new alternatives. Structural Equation Modeling, 6(1), 1-55.

Hur, Y., Ko, Y., \& Valacich, J. (2007). Motivation and concerns for online sport consumption. Journal of Sport Management, 21(4), $521-539$.

Hwang, J. S., \& McMillan, S. J. (2002). The role of interactivity and involvement in attitude toward the website. In Proceedings of the 2002 Conference of the American Academy of Advertising, Auburn, AL: Auburn University.

Internet World Stats. (2011). Internet usage statistics. Retrieved November 22, 2011, from http://www.internetworldstats.com/stats.htm

Jackson, C. M., Chow, S., \& Leitch, R. A. (2007). Toward an understanding of the behavioral intention to use an information system. Decision Sciences, 28(2), 357-389.

Kang, S., Lee, S., \& Lee, S. (2010). Student athletes' sport-program viewing: Motives and preferences. International Journal of Sport Communication, 3(3), 335-370.

Karjaluoto, H., Mattila, M., \& Pento, T. (2002). Factors underlying attitude formation towards online banking in Finland. International Journal of Bank Marketing, 20(6), 261-272.

Ko, H., Cho, C., \& Roberts, M. S. (2005). Internet uses and gratifications : A structural equation model of interactive advertising. Journal of Advertising, 34(2), 57-70.

Korgaonkar, P., \& Wolin, L. (1999). A multivariate analysis of web usage. Journal of Advertising Research, 39(2), 53-68.

Lin, C. A. (1999). Online-service adoption likelihood. Journal of Advertising Research, 39(2), 79-89.

Liu, Y. (2003). Developing a scale to measure the interactivity of websites. Journal of Advertising Research, 43(2), $207-213$.

Luo, X. (2002). Uses and gratifications theory and e-consumer behaviors: A structural equation modeling study. Journal of Interactive Advertising, 2(2), 34-41.

Madden, M. (2003). America's online pursuits: The changing picture of who's online andwhat they do. Pew Internet and American Life. Retrieved November 22, 2011, from http://www.pewinternet.org/PPF/r/106/report_display.asp.

Millar, M. G., \& Millar, K. U. (1996). Effects of direct and indirect experience on affective and cognitive responses and the attitudebehavior relation. Journal of Experimental Social Psychology, 32(6), 561-579.

Millar, M. G., \& Tesser, A. (1986). Effects of affective and cognitive focus on the attitude-behavior relation. Journal of Personality and Social Psychology, 51(2), 270-276.

Newhagen, J. E., \& Rafaeli, S. (1996). Why communication researchers should study the Internet: A dialogue. Journal of Communication, 46(1), 4-13.

Nunnally, J. C., \& Bernstein, I. H. (1994). Psychometric theory. McGraw, New York.

O'Keefe, R. M., O'Connor, G., \& Kung, H. J. (1998). Early adopters of the Web as a retail medium: Small company winners and losers. European Journal of Marketing, 32(7/8), 629-643.

Ostrom, T. M. (1969). The relationship between the affective, behavioral, and cognitive components of attitude. Journal of Experimental 
Social Psychology, 5(1), 12-30.

Papacharissi, Z., \& Rubin, A. M. (2000). Predictors of Internet use. Journal of Broadcasting and Electronic Media, 44(2), 175-196.

Perse, E. M., Burton, P. I., Kovner, E. S., \& Lears, M. E., \& Sen, R. J. (1992). Predicting computer-mediated communication in a college class. Communication Research Reports, 9(2), 161-170.

Petty, R. E., Wegener, D. T., \& Fabrigar, L. R. (1997). Attitude and attitude change. Annual Review of Psychology, 48, 609-647.

Pew Research Center (2009). Pew Internet and American life project: Adults on social network sites, 2005-2009. Retrieved November 13, 2011, from http://pewinternet.org/Infographics/Growth-in-Adult-SNS-Use-20052009.aspx

Pope, N., Brown, M., \& Forrest, E. (1999). Risk, innovativeness, gender, and involvement factors affecting the intention to purchase sport products online. Sport Marketing Quarterly, 8(2), 25-41.

Raney, A. A. (2006). Why we watch and enjoy mediated sports. In A. A. Raney \& J. Bryant (Eds.), Handbook of sports and media (pp. 171-184). Hillsdale, NJ: Lawrence Erlbaum Associates, Inc.

Rodgers, S., \& Sheldon, K. M. (2002). An improved way to characterize Internet users. Journal of Advertising Research, 42(5), 85-94.

Rubin, A. M. (1983). Television uses and gratifications: The interactions of viewing patterns and motivations. Journal of Broadcasting, 27(1), 37-52.

Rubin, A. M. (1993). Audience activity and media use. Communication Monographs, 60(1), 98-105.

Rubin, A. M. (1994). Media uses and effects: A uses and gratifications perspective. In J. Bryant \& D. Zillmann (Eds.), Media effects: Advances in theory and research (pp. 417-436). Hillsdale, NJ: Lawrence Erlbaum Associates.

Rubin, A. M., \& Bantz, C. R. (1987). Utility of videocassette recorders. In J. L. Salvaggio \& J. Bryant (Eds.), Media use in the information age: Emerging patterns of adoption and consumer use (pp. 181-195). Hillsdale, NJ: Erlbaum.

Severin, W. J., \& Tankard, J. W. (1997). Communication theories: Origins, methods, and uses in the mass media (4th ed.). White Plains, NY: Longman.

Sheeran, P. (2002). Intention-behavior relations: A conceptual and empirical review. European Review of Social Psychology, 12 (1), 1-36.

Smith, R. L., Pent, A. K., \& Pitts, B. G. (1999). The World wide Web as an advertising medium for sport facilities: An analysis of current use. Sport Marketing Quarterly, 9(10), 31-34.

Stoldt, G. C., Dittmore, S. W., \& Pedersen, P. M. (2011). Communication in the sport industry. In P. M. Pedersen, J. B. Parks, J. Quarterman, \& L. Thibault (Eds.), Contemporary sport management (pp. 270-289). Champaign, IL: Human Kinetics.

Subrahmanyam, K., \& Greenfield, P. M. (2008). Communicating online: Adolescent relationships and the media. The Future of Children: Children and Media Technology, 18(1), 119-146.

Subrahmanyam, K., Reich, S. M., Waechter, N., \& Espinoza, G. (2008). Online and offline social networks: Use of social networking sites by emerging adults. Journal of Applied Developmental Psychology, 29(6), 420-433.

Swanson, D. L. (1987). Gratification seeking, media exposure, and audience interpretations: Some directions for research. Journal of Broadcasting and Electronic Media, 31(3), 237-254.

Szajna, B. (1996). Empirical evaluation of the revised technology acceptance model. Management Science, 42(1), 85-92.

Tabachnick, B. G., Fidell, L. S., \& Osterlind, S. J. (2001). Using multivariate statistics.

Top Site Blog (2011). Top 10 most popular sports websites. Retrieved November 22, 2011, from http://topsiteblog.com/best-sportswebsites/

Triandis, H. (1971). Attitude and attitude change. New York: John Wiley \& Sons, Inc.

Valois, P., Desharnais, R., \& Godin, G. (1988). A comparison of the Fishbein and Ajzen and the Triandis attitudinal models for the prediction of exercise intention and behavior. Journal of Behavioral Medicine, 11(5), 459-472.

Wann, D. L. (1995). Preliminary validation of the sport fan motivation scale. Journal of Sport and Social Issues, 20(4), $377-396$. 


\title{
국문초록
}

\section{스포츠 웹사이트 사용자들의 동기척도 개발 : 정서적 태도와 행동 의사에 관한 동기요인의 관점}

\author{
이순환 · 최완용 · 신홍범 · 최형준
}

본 연구의 목적은 스포츠 웹사이트 사용자들의 동기척도를 U\&G 이론 (Uses and Gratifications Theory)을 적용 하여 개발하고, 인지적 - 정서적 태도에 관한 다양한 동기의 영향 및 스포츠 웹사이트 이용과 관련한 행동 의사의 영향을 살펴보는 것이다. 데이터 분석을 위해, 7 점 척도로 구성된 22개 문항의 설문지를 이용, 총 505 명의 설문응 답을 확인적 요인분석과 구조방정식 모형으로 분석하였으며. 분석결과 각각 만족할만한 데이터 구성과 모형을 가 진 것으로 파악되었다. 특히, 총 5가지의 동기요인 중, 4 가지 동기 요인- 정보,상호작용, 오락, 경제- 에서는 인지 적 - 정서적 태도에 유의미한 영향이 있었으나, 편의성 요인은 부정적인 영향을 가진 것으로 나타났다. 또한, 인지 적 태도만이 스포츠웹사이트 사용과 관련, 긍정적인 영향을 미치는 것으로 파악되었다. 본 연구는 스포츠 웹사이 트 사용자들의 동기척도를 개발하기 위해 U\&G 이론을 적용한 첫번째 연구이며, 본 연구결과를 통하여 스포츠 웹 사이트 관련 실무자들에게 구체적인 목표와 운영내용을 제시할 수 있다.

주요어 : 이용과 충족(U\&G) 이론, 스포츠 웹사이트 사용자, 인지, 정서적 태도, 동기 